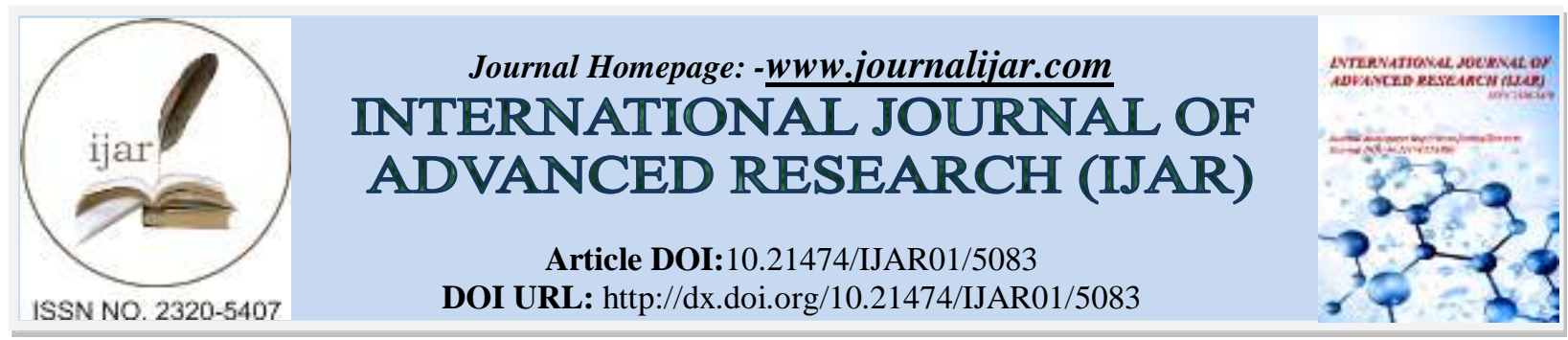

RESEARCH ARTICLE

\title{
A STUDY OF TEACHERS' EFFECTIVENESS IN REFERENCE TO LEADERSHIP BEHAVIOR OF PRINCIPALS OF SECONDARY SCHOOLS.
}

\author{
Dr. Pramod Joshi ${ }^{1}$ and Dr. Sumati Rani ${ }^{2}$. \\ 1. Assistant Professor, School of Education, Central University of Haryana, Haryana. India. \\ 2. Assistant Teacher, Dept. of Education, Government Girls Inter College, Parkham, Mathura. India.
}

\section{Manuscript Info}

Manuscript History

Received: 06 June 2017

Final Accepted: 08 July 2017

Published: August 2017

Key Words:-

Teachers' Effectiveness, Leadership

Behavior, and Secondary Schools.

\begin{abstract}
The main aim of this research was to study the teachers' effectiveness in reference to leadership behavior of principals. For fulfill the main aim of the study the researcher framed following objectives: to study the leadership behavior of principals and to study the teachers 'effectiveness in reference to leadership behavior of principals. Descriptive survey method was employed and the present study was confined to the principals (20 male and 20 female) and 200 teachers of 40 secondary schools affiliated to U.P. Board of Education purposively. Leader Behavior Scale (LBS) developed by Dr. Asha Hinger and Kulsum Teacher Effectiveness Scale (KTES) were used for data collection of leadership behavior of principals and effectiveness of teachers respectively. Mean. S.D. and C.R. Value were calculated to analysis the data. The result of the study concluded that gender differences do not exist in relation to leadership behavior of principals as both male and female principals are provided equal facilities. The leadership behaviour of school principals positively influences teachers' effectiveness. It differs with differential effectiveness of leadership behavior of principals.
\end{abstract}

Copy Right, IJAR, 2017,.All rights reserved.

\section{Introduction:-}

Effective teachers must possess the knowledge and skills needed to attain the goals, and must be able to use that knowledge and those skills appropriately if these goals are to be achieved. In Medley and Shannon (1994)terms, the possession of knowledge and skills falls under the heading of 'teacher competence' and the use of knowledge and skills in the classroom is referred to as 'teacher performance', Teacher competence and teacher performance with the accomplishment of teacher goals, is the 'teacher effectiveness'. Four major assumptions are implicit in this definition of teacher effectiveness. It is important for principals to make their teachers feel that they are supported in order to keep quality teachers in the profession. Ryans (2007) examined the relationship between principal leadership behaviors and teachers' sense of self-efficacy and the data from this study indicated positive correlation between them. Principals have the power to influence many factors of a school. They have a myriad of roles included in their job. One of the most important and influential is the effect the principal has on the teachers of the school.

\section{Review of Related Literature:-}

The brief account of the previous researches related leadership behavior and teachers' effectiveness is presented as: 
Zaid and Vali (2016) studied leaderships behavior and its relation with principals' management, Roghaiyeh, S.S. and Pravenna, K.B. (2013) conducted a study on influence of gender and type of school on leadership behavior among school teachers, Ko, J., Sammons, P., and Bakkum, L. (2013) conducted a study on effective teaching: a review of research and evidence, Calaguas, G.M. (2012) examined teacher effectiveness scale in higher education: development and psychometric properties, Martin, T.R. (2011) examined the relationship between principal leadership behavior and principal experience, Chingos, M. M. (2010) conducted teacher effectiveness in classroom unrelated to the college teacher attended, Sodhi, B. (2010) studied on teacher effectiveness of secondary school teachers of Punjab in relation to school organizational climate, Sambatur, S. (2009) conducted an exploratory study on teaching effectiveness and research productivity in higher technical education institutions in India and Davitt, S. J.(2008)examined an exploratory study of principal innovativeness and leadership behavior. The researches still need to be conducted to see the leadership behavior of principals as the predictor of teachers' effectiveness of the present stud.

\section{Objectives of the Study:-}

1. To study the leadership behavior of principals in relation to gender.

2. To study the teachers 'effectiveness in relation to leadership behavior of principals.

\section{Hypothesis of the Study:-}

There exists no significant difference in the teachers' effectiveness in relation to leadership behavior of principals.

\section{Methodology:-}

Method of the Study:-

The researcher has adopted descriptive survey method for the present study.

\section{Sample Selection:-}

The present study was confined to the principals (20 male and 20 female) and 200 teachers of 40 secondary schools affiliated to U.P. Board of Education. The purposively method of the sampling was used in selection of the sample of the study.

\section{Tools \& Techniques of Data Collection:-}

Leader Behavior Scale (LBS) developed by Dr. Asha Hinger and Kulsum Teacher Effectiveness Scale (KTES)were used for data collection. LBS help in identifying various dimensions of leadership behavior in terms of effectiveness on the basis of self-perception and KTES helps in identifying the effectiveness of teachers.

\section{Statistical techniques used:-}

Mean. S.D. and t- Value were calculated to analysis the data.

\section{Result and Discussion:-}

The data collected is tabulated and the results obtained are presented under the following headings:

\section{To Study Leadership Behavior of Principals in Relation to Gender:-}

The researcher analysis the data in order to study the leadership behavior of male and female principals, values of Mean and standard deviation have been calculated and to study the gender difference in leadership behavior, $t$-value has been obtained and given in the table 1 .

Table-1:- Showing Mean, S.D. and t-value for Leadership Behavior of Male and Female Principals.

\begin{tabular}{|c|c|c|c|c|c|c|c|}
\hline \multirow{3}{*}{$\begin{array}{c}\text { Leadership } \\
\text { Behavior }\end{array}$} & Gender & $\mathbf{N}$ & Mean & S.D. & t-value & df & $\begin{array}{c}\text { Level of } \\
\text { significance }\end{array}$ \\
\hline & Male & 20 & 119.82 & 13.43 & \multirow[t]{2}{*}{0.68} & \multirow[t]{2}{*}{39} & \multirow{2}{*}{$\begin{array}{c}\text { Not } \\
\text { significant at } \\
0.05 \text { level }\end{array}$} \\
\hline & Female & 20 & 115.81 & 12.97 & & & \\
\hline
\end{tabular}

From the above table, it is inferred that mean values of leadership behavior for male and female principals are 119.82 and 115.81 respectively and related value of standard deviation are 13.43 and 12.92 respectively. The calculated t-value between male and female principals regarding their leadership behavior has been found 0.68 which is less than table value at 39 degree of freedom on 0.05 level of confidence. Hence, it can be said that there 
exists no significant difference between leadership behavior of male and female principals or in other words it can be said that gender has no effect on leadership behavior of principals. This may be due to the reason that leadership behavior upto some extent depends on the environmental exposure or situations available.

To Study the Teachers' Effectiveness in Reference to the Leadership Behavior (Most, Moderate and Least Effectiveness) of Principals:-

The researcher analyzed the data of teacher's effectiveness separately from the schools having their principals with most, moderate and least effective leadership behavior. The researcher calculated mean values, standard deviation and t-value for teachers' effectiveness in reference to leadership behavior of their school principals which are shown in the table 2-

Table 2:-Showing Mean, S.D. and t-value for Teachers' Effectiveness in reference to Leadership Behavior Principals

\begin{tabular}{|c|c|c|c|c|c|}
\hline \multirow[t]{2}{*}{ LB Effectiveness } & \multicolumn{3}{|c|}{ School Learning Culture } & \multirow[t]{2}{*}{ t-value } & \multirow{2}{*}{$\begin{array}{c}\text { Level of } \\
\text { significance }\end{array}$} \\
\hline & $\mathbf{N}$ & $\mathbf{M}$ & S.D. & & \\
\hline $\begin{array}{l}\text { Most } \\
\text { Moderate }\end{array}$ & $\begin{array}{l}60 \\
85\end{array}$ & $\begin{array}{l}463.39 \\
451.06\end{array}$ & $\begin{array}{l}14.05 \\
14.14\end{array}$ & 5.63 & Significant at 0.01 \\
\hline $\begin{array}{l}\text { Moderate } \\
\text { Least }\end{array}$ & $\begin{array}{l}85 \\
55\end{array}$ & $\begin{array}{l}451.06 \\
432.93\end{array}$ & $\begin{array}{l}14.14 \\
14.31\end{array}$ & 6.91 & Significant at 0.01 \\
\hline $\begin{array}{l}\text { Most } \\
\text { Least }\end{array}$ & $\begin{array}{l}60 \\
55\end{array}$ & $\begin{array}{l}463.39 \\
432.93 \\
\end{array}$ & $\begin{array}{l}14.05 \\
14.31\end{array}$ & 11.46 & Significant at 0.01 \\
\hline
\end{tabular}

It is inferred from above table that the mean values of teachers' effectiveness having principals with most, moderate and least effective leadership behavior are found 463.39, 451.06 and 432.93 respectively and their respective values of standard deviation are $14.05,14.14$ and 14.31. It is notable that the mean values of teachers' effectiveness seems to be decreasing with most; moderate and least effective leadership behavior of their principals i.e., the mean of the teachers' effectiveness having principals with most effective leadership behavior is more than of those staff having principals with moderate and least effective leadership behavior.

The obtained t-values were used to study the significant differences in effectiveness of teachers having principals with most, moderate and least effective leadership behavior. The t-value for effectiveness of teachers in relation to principals with most and moderate effective leadership behavior was found 5.63 which is significant at 0.01 level of confidence and similarly, the t-values for teachers' effectiveness in relation to principals with moderate and least and most and least effective leadership behavior were found 6.91and 11.46 respectively and both were found significant at 0.01 level of confidence. As all the t-values were found significant at 0.01 level of significance hence, the hypothesis that "There exists no significant difference in the teachers' effectiveness in relation to leadership behavior of principals" is rejected.

It is revealed from the analysis that the leadership behavior of the principals influences the effectiveness of their teachers. As the principal's leadership was effective so was the effectiveness of teachers found. It may be due to the reason that the proper management of school curriculum guided by principals and the facilities provided to the teachers directly or indirectly influence the preparation and planning for teaching done by teachers and the classroom management, discipline, motivation, interaction and evaluation which is one of the measure of determining a teacher's effectiveness are also affected by leadership provided by principals as they are responsible for the supervision of all these things being properly done by teachers. The interpersonal relations of teachers are also affected by congenial climate formed by the principals in the schools. These results are also verified with the study of Umme, K. (1999) who studied leadership dimensions of secondary schools heads as perceived by effective and ineffective teachers. It was found that there was positive and significant relationship between the perception of leadership dimensions \& teachers' effectiveness in different areas.

\section{Conclusion of the Study:-}

The result of the present study concludes that gender differences do not exist in relation to leadership behavior of principals as both male and female principals are provided equal facilities and other incentives and are exposed to similar kind of organizational atmosphere getting almost similar stimuli to respond hence they do not differ in their 
leadership behavior. The leadership behaviour of school principals positively influences teachers' effectiveness. It differs with differential effectiveness of leadership behavior of principals.

\section{References:-}

1. Calaguas, G.M. (2012). Teacher Effectiveness Scale in Higher Education: Development and Psychometric Properties. International Journal of Research Studies in Education, 2(2).

2. Chingos, M. M. (2010).Teacher effectiveness in Classroom Unrelated to the College Teacher Attended. A Work of Program on Education Policy and Governance (PEPG), Harvard University. Retrieved from: www.hks. harvard.edu/pepg/MeritPayPapers/Chingos

3. Davitt, S. J. (2008). An Exploratory Study of Principal Innovativeness and Leadership Behavior, (Doctoral Dissertation). Retrieved from: https:// scholarsbank.uoregon.edu/.../Davit...

4. Deal, T. E. and Peterson, K .D. (1990). The Principal's role in Shaping School Culture.Washington:DC. Office of Educational Research and Improvement.

5. Dubey, A. (2016). Leadership Behavior of Principals as the Predictor of School Learning Culture, Students' Achievement and Some of the Characteristics of Teachers. http.www.shodhganga.com.

6. Ko, J., Sammons, P., and Bakkum, L. (2013). Effective Teaching: A Review of Research and Evidence.

7. Lyons, B.J. (2010). Principal Instructional Leadership Behavior as Perceived by Teachers and Principals, at New York State Recognized and Non-Recognized Middle Schools. (Doctoral dissertation, Seton Hall University). Retrieved from: http://scholarship . shu.edu /dissertations /1401

8. Martin, T.R. (2011). The Relationship between Principal Leadership Behavior and Principal Experience. Retrieved from: ProQuest Dissertations and Theses.

9. Medley, D.M. and Shannon, D.M. (1994). Teacher Evaluation. In T. Husen and T. N. Postlethwaite (Eds.), The International Encyclopedia of Education, $2^{\text {nd }}$ edn., 10, 6015-6020. Oxford: Pergamon.

10. Roghaiyeh, S.S. \& Pravenna, K.B. (2013). Influence of Gender and Type of School on Leadership Behavior among School Teachers. Paripex - Indian Journal of Research, 2(8).

11. Ryans, H.D.(2007).An Examination of the Relationship between Teacher Efficacy and Teachers' Perceptions of their Principals' Leadership Behaviors (Doctoral dissertation).College of Education, University of North Texas.

12. Sambatur, S.(2009). An Exploratory Study on Teaching Effectiveness and Research Productivity in Higher Technical Education Institutions in India. (Doctoral dissertation). National Institute of Technology Karnataka, Surathkal, India.

13. Umme, K. (1999). Leadership Dimensions of Secondary School Heads as Perceived by Effective \& Ineffective Teachers. Experiments in Education, 27(12), 234.

14. Zaid and Vali (2016). Leaderships Behavior and Its relation with Principals' Management, New Approaches in Educational Research, Vol.5 No.1 